\title{
Genotypic and Phenotypic Characterization of Side Population of Gastric Cancer Cell Lines
}

\author{
Rosa Schmuck, ${ }^{*}$ Viktoria Warneke, ${ }^{\dagger}$ \\ Hans-Michael Behrens, ${ }^{\dagger}$ Eva Simon, ${ }^{\dagger}$ \\ Wilko Weichert, ${ }^{\ddagger}$ and Christoph Röcken ${ }^{\dagger}$ \\ From the Department of Pathology, " Charité University Hospital, \\ Berlin; the Department of Pathology, ${ }^{\dagger}$ Christian-Albrechts- \\ University, Kiel; and the Department of Pathology, ${ }^{\ddagger}$ uprecht- \\ Karls-University, Heidelberg, Germany
}

The side population (SP) of tumor cell lines shares characteristics with tumor stem cells. The objective of this study was to phenotypically and genotypically characterize the SP of gastric cancer cell lines. SP cells were obtained from AGS and MKN45 gastric cancer cells using Hoechst 33342 staining and fluorescenceactivated cell sorting. The cells were subsequently studied morphologically at cytology and immunocytochemistry, on the transcriptional level via gene array, and in cell culture using recultivation assays. Genes differentially expressed in SP cells were evaluated at immunohistochemistry in tissue samples from 486 patients with gastric cancer. The SP cells were smaller and rounder then non-SP cells. SP cells selfrenewed in recultivation experiments and differentiated into SP and non-SP cells. Recultivated SP and non-SP cells exhibited distinct phenotypes in culture insofar as cell shape and colony formation. SP cells demonstrated increased levels of the stem cell markers CD133 and Musashi-1. Transcriptional analyses demonstrated that SP cells express genes that encode for stem cell properties including FZD7, HEY1, SMO, and ADAM17. It was observed that ADAM17 and FZD7 are differentially expressed in human gastric cancer, and FZD7-positive cancers are associated with significantly shorter patient survival. In conclusion, human gastric cancer cell lines enclose a phenotypically and genotypically distinct cell population with tumor stem cell features. Phenotypic characteristics of this distinct cell population are also present in gastric cancer tissue, and correlate with patient survival. (Am J Pathol 2011, 178:1792-1804; DOI: 10.1016/j.ajpath.2010.12.043)

Gastric cancer is among the most common malignant diseases worldwide and is associated with a poor prognosis. More than $80 \%$ of patients with advanced gastric cancer die of the disease within 1 year after diagnosis. Although chemotherapy improves life expectancy, many patients die of recurrent disease, which suggests that standard treatment protocols are ineffective in a considerable number of cases. ${ }^{1}$ A putative explanation for ineffective therapy is the presence of cancer stem cells (CSCs). The CSC hypothesis postulates that a tumor is a conglomerate of heterogeneous cell populations. Only a subpopulation of this conglomerate maintains the capability for excessive proliferation. In some studies, as few as 100 cells of the CSC subpopulation induced tumor growth in immunodeficient mice. ${ }^{2}$ Those cells exhibit stem cell features and give rise to phenotypically diverse cancer cells. CSCs are more resistant to therapy, leading to tumor recurrence, progression, and, ultimately, patient death. ${ }^{3,4}$

The role of CSCs in gastrointestinal cancer in general and in gastric cancer in particular has not been fully clarified. One of the problems associated with identification and characterization of stem cells is their separation from the surrounding cell population. Although promising efforts have been made to isolate CSCs in gastric cancer by using surface markers such as CD $44,{ }^{5}$ this method is impractical in most tissues because there are only a few known surface marker profiles for stem cells, and those identified differ between stem cells of different tissues. A novel approach to identification and characterization of a tumor cell subpopulation with putative stem cell features is use of the side population (SP) of cancer cell lines. The SP is characterized by the ability to efflux the DNA-binding dye Hoechst 33342. It was first described in 1996 in a pioneering study by Goodell et $\mathrm{al}^{6}$ in which a subpopulation of hematopoietic cells with a low staining profile was discovered. This small subset of cells $(0.2 \%)$ exhibited a Sca- $1^{\text {pos }}$ Lin ${ }^{\text {neg/low }}$ surface marker profile characteristic of hematopoietic progenitor cells. A small number of these SP cells could rebuild bone marrow in mice administered sublethal dosages of irradiation, whereas the other cells could not. Progress has been made to advance our understanding of these cells. Not only do SP cells represent the stem cell subset in various tissues such as brain, liver, and kidney, they also seem to have a vital role in cancer genesis in

\footnotetext{
Accepted for publication December 23, 2010.
}

Supplemental material for this article can be found at http://ajp. amjpathol.org or at doi:10.1016/j.ajpath.2010.12.043.

Address reprint requests to Christoph Röcken, M.D., Department of Pathology, Christian-Albrechts-University, Arnold-Heller-Str 3, Haus 14, D-24105 Kiel, Germany. E-mail: christoph.roecken@uk-sh.de. 
leukemia $^{7}$ and solid tumors. ${ }^{8}$ The mechanism of the characteristic staining pattern of SP cells is based on their ability to efflux Hoechst 33342 dye via ATP-binding cassette $(\mathrm{ABC})$ transporters. $\mathrm{ABC}$ transporters seem to correlate with maintenance of stem cell features. ${ }^{9}$

The present study was based on the hypotheses that i) gastric cancer contains a tumor cell subpopulation that demonstrates stem cell characteristics and that determines tumor recurrence and progression, ii) this population can be identified by sorting for SP cells, and iii) phenotypic and genotypic characterization of these cells may aid in identification of novel therapeutic targets for treatment of gastric cancer. Using Hoechst 33342 dye and gastric cancer cell lines, SP cells were isolated and characterized phenotypically, genotypically, and in recultivation experiments. Genes differentially expressed in SP cells were evaluated at immunohistochemistry in tissue samples from patients with gastric cancer.

\section{Materials and Methods}

\section{Cell Lines and Cell Culture}

The human gastric cancer cell line AGS was obtained from the American Type Culture Collection (Wesel, Germany), and MKN 45 from the German Collection of Microorganisms and Cell Cultures (Braunschweig, Germany). Both cell lines were derived from adenocarcinomas of the intestinal type according to the Lauren classification. The cells were grown in VLE RPMI 1640 medium supplemented with 10\% (AGS) or 20\% (MKN 45) fetal bovine serum (Biochrom AG, Berlin, Germany) at $37^{\circ} \mathrm{C}$ in a humidified atmosphere with $5 \% \mathrm{CO}_{2}$. For recultivation experiments, the cell culture medium was supplemented with $10 \mu \mathrm{L} / \mathrm{mL}$ penicillin or streptomycin (PAA Laboratories GmbH, Pasching, Austria). Cells were washed with PBS, and harvested by incubating for 5 minutes with trypsin. Trypsin was inhibited by addition of culture medium, and the cells were pelleted via centrifugation for 5 minutes at $800 \mathrm{rpm}$. The cells were resuspended in culture medium, counted using a Z1 Coulter cell counter (Beckman Coulter $\mathrm{GmbH}$, Krefeld, Germany), and aliquoted in portions of $1 \times 10^{6}$ cells. All experiments were performed in a culture hood, and all cell culture solutions were preheated to $37^{\circ} \mathrm{C}$ before use.

\section{Hoechst Staining}

Staining with Hoechst 33342 dye (B2261; Sigma-Aldrich Corp., St Louis, MO) was performed according to the method of Lin and Goodell. ${ }^{10}$ In brief, gastric cancer cells were detached at trypsinization, and $1 \times 10^{6}$ cells were incubated in the growth medium with $2.5,4.0,5.0,6.0,8.0$, or $10.0 \mu \mathrm{g} / \mathrm{mL}$ Hoechst 33342 either alone or in combination with $50 \mu \mathrm{g} / \mathrm{mL}$ verapamil at $37^{\circ} \mathrm{C}$ for 90 minutes in the dark, with interval mixing. After washing with PBS or $2 \%$ fetal bovine serum, the cells were incubated with $2 \mu \mathrm{g} / \mathrm{mL}$ propidium iodide to exclude nonviable cells demonstrating uptake. The freshly harvested cells were washed with ice-cold PBS and filtered with a 30- $\mu \mathrm{m}$ cell filter (Partec $\mathrm{GmbH}$, Görlitz, Germany) to prevent clogging of the fluorescence- activated cell-sorting (FACS) devices. After staining, cells were kept in the dark on ice to prevent further dye efflux.

\section{Fluorescence-Activated Cell Sorting}

FACS was performed using the FACS DIVA instrument (BD Biosciences, San Jose, CA). The Hoechst dye was excited with a UV laser (350 nm), and fluorescence was measured using both a 675/20 filter (Hoechst red) and a 450/20 filter (Hoechst blue). Hoechst fluorescence was displayed on a blue versus red plot, with blue on the vertical axis and red on the horizontal axis, both in linear mode. The voltage was adjusted so that the propidium iodide-positive cells accumulated along the rightmost vertical line. Most cells were located in the center and upper right. The SP cells concentrated on a diagonal line in the lower left.

\section{Recultivation Assays}

After FACS sorting, SP and non-SP cells were cultured separately in small cell culture flasks and photographed every other day. The cells were then harvested, stained with Hoechst 33342, and reanalyzed with FACS after 6 to 10 days, as described. AGS cells were used for recultivation assays, and three separate sortings were performed that resulted in six samples, three SP and three non-SP.

\section{Cell Viability}

Cell viability was studied before and after Hoechst 33342-staining and before and after FACS analysis. Cells were washed with PBS, fixed in $100 \%$ ethanol, and counterstained with $1 \%$ methylene blue.

\section{Cytology and Immunocytochemistry}

The morphologic features and immunophenotype of SP and non-SP cells were studied at cytology and immunocytochemistry. Approximately $1 \times 10^{4}$ to $1 \times 10^{6}$ AGS cells were cytocentrifuged for 10 minutes at $1000 \mathrm{rpm}$ onto glass slides and fixed in a 7:3 acetone-methanol mixture for 20 minutes at $-20^{\circ} \mathrm{C}$. The number of SP and non-SP cells obtained from MKN45 was too small to generate an adequate number of slides at cytocentrifugation for all phenotypic analyses. Therefore, MKN45 cells were embedded in small agarose beads as follows: MKN45 cells were fixed in $4 \% p$-formaldehyde overnight and pelleted in an Eppendorf tube via centrifugation for 5 minutes at 3500 rpm, and washed twice in PBS. The Eppendorf tube was weighed without and with the cell pellet. An amount of $2 \%$ low-melt agarose solution identical to the mass (in micrograms) of the cell pellet was added to the cells. The fixed cells were suspended in the warm $2 \%$ low-melt agarose solution and placed on parafilm. The agarose cell suspension was hardened in a refrigerator at $-20^{\circ} \mathrm{C}$ for at least 10 minutes, processed using a conventional tissue processor (Leica TP; Global Medical Instrumentation Inc., Ramsey, $\mathrm{MN}$ ), and manually embedded in paraffin. Paraffin sections $3 \mu \mathrm{m}$ thick were mounted on glass slides, dewaxed in xylene, rehydrated in a descending $(96 \%, 70 \%$, and $50 \%)$ ethanol series, and stained. 
Cell size and morphologic features were assessed at H\&E staining. The cells were immunostained using monoclonal antibodies directed against CD44 (diluted 1:100; Biozol Diagnostica Vertrieb GmbH, Eching, Germany) and CD133 (1:100; Cell Signaling Technology, Inc., Beverly, MA), and polyclonal antibodies directed against CD117 (1:100; Dako Cytomation A/S, Glostrup, Denmark), LGR5 (1:400; Abcam, Inc., Cambridge, MA), and Musashi-1 (MSI-1; 1:100; Chemicon International Inc., Temecula, CA). For immunocytochemistry, cells and sections were pretreated with an avidin-biotin block (Corning Inc., Corning, NY) before antibody staining to minimize unspecific staining reaction. Incubation with the primary antibodies was performed in a moist chamber at room temperature for 30 minutes and then at $4^{\circ} \mathrm{C}$ overnight. Paraffin sections were pretreated with sodium citrate $(\mathrm{pH}$ 6.0) before staining with anti-LGR5 antibody. Slides were washed between steps with Tris-buffered saline solution. Immunoreactions were visualized using the Super Sensitive Link Label Detection System (BioGenex Laboratories, San Ramon, CA) combined with the SIGMAFAST kit (Sigma-Aldrich Corp.) according to the manufacturer's instructions. Specimens were counterstained with hematoxylin. Omission of primary antibodies served as negative controls. Nonneoplastic human stomach (CD44), appendix (CD117), colon cancer (CD133), kidney (FZD7), and brain (LGR5 and MSI-1) tissue served as positive controls, and demonstrated cytoplasmic staining in neurons (LGR5 and MSI-1), mast cells (CD117), inflammatory cells (CD44), tubular epithelium (FZD7), and tumor cells (CD133). No staining was observed after omission of the primary antibodies.

The percentage of immunoreactive cells was evaluated by counting the number of immunoreactive cells among at least $80 \mathrm{SP}$ and non-SP cells, respectively, in at least five visual fields (400X magnification). In a second step, the intensity of immunoreaction was assessed as negative (0), weak (1), moderate (2), strong (3), or very strong (4).

\section{RNA Extraction and Gene Chip Analysis}

RNA was extracted using a mirVana miRNA Isolation Kit (Ambion, Inc., Austin, TX) according to the manufacturer's instructions. The total RNA was quantified using UV spectroscopy, and its quality was assessed using a LabChip (BioAnalyzer, Agilent Technologies, Inc., Santa Clara, CA) and agarose gel electrophoresis. cDNA was synthesized from $5 \mu \mathrm{g}$ total RNA. Reverse transcription was performed at $43^{\circ} \mathrm{C}$ for 90 minutes in first-strand buffer, and second-strand synthesis was performed in 150 $\mu \mathrm{L}$ solution using the complete $\mathrm{cDNA}$ reaction mixture (both from Invitrogen Corp., Karlsruhe, Germany). The mixture was incubated at $16^{\circ} \mathrm{C}$ for 2 hours, followed by further incubation with $2 \mu \mathrm{L}$ T4 DNA polymerase $(5 \mathrm{U} / \mu \mathrm{L})$ for 15 minutes. Cleanup of double-stranded cDNA was performed using phenol or chloroform extraction and precipitation with $5 \mathrm{mmol} / \mathrm{L}$ ammonium acetate and absolute ethanol at $-20^{\circ} \mathrm{C}$ for 20 minutes. Synthesis of biotinlabeled cRNA was performed using the BioArray High Yield RNA Transcription kit (Enzo Diagnostics Inc., Farmingdale, NY). The amplified cRNA was purified with an affinity resin column (RNeasy; Qiagen $\mathrm{GmbH}$, Hilden, Germany) and fragmented at incubation at $94^{\circ} \mathrm{C}$ for 35 minutes in the presence of $40 \mathrm{mmol} / \mathrm{L}$ Tris acetate $(\mathrm{pH}$ 8.1), $100 \mathrm{mmol} / \mathrm{L}$ potassium acetate, and $30 \mathrm{mmol} / \mathrm{L}$ magnesium acetate. The cRNA amount was determined at UV spectroscopy, and distribution of cRNA fragment sizes of both CRNA and fragmentation products was checked by analyzing the samples using a LabChip BioAnalyzer (Agilent Technologies, Inc.). The fragmented cRNA was hybridized to the HG U133A/MG U74Av2 array (Affymetrix, Inc., Santa Clara, CA). Hybridization was then performed at $45^{\circ} \mathrm{C}$ in a hybridization oven for 16 hours. Subsequent washing and staining of the arrays was performed using the GeneChip fluidics station protocol EukGE-WS2. The arrays were stained for 10 minutes in streptavidin-phycoerythrin solution (Molecular Probes, Inc., Eugene, $\mathrm{OR}$ ) at $25^{\circ} \mathrm{C}$. The post-stain wash consisted of 10 cycles at $25^{\circ} \mathrm{C}$ in the fluidics station using nonstringent solution. The probe arrays were treated for $10 \mathrm{~min}$ utes in antibody solution composed of $2 \mu \mathrm{g} / \mu \mathrm{L}$ acetylated bovine serum albumin, $0.1 \mu \mathrm{g} / \mu \mathrm{L}$ normal goat IgG (Sigma-Aldrich Corp.), and $3 \mu \mathrm{g} / \mathrm{mL}$ goat anti-streptavidin biotinylated antibody (Vector Laboratories, Inc., Burlingame, CA) in $100 \mathrm{mmol} / \mathrm{L} \mathrm{MES,} 1 \mathrm{mmol} / \mathrm{L} \mathrm{NaCl}$, and $0.05 \%$ Tween 20 at $25^{\circ} \mathrm{C}$. After washing and staining, probe arrays were scanned twice at $3-\mu \mathrm{m}$ resolution using the GeneChip System confocal scanner (HewlettPackard, Santa Clara, CA).

\section{Bioinformatics}

Raw data were analyzed using GeneChip Operating Software, version 1.4 (Affymetrix, Inc.). The $P$ value of a transcript determines the detection call, which indicates whether the transcript is reliably detected $(P<0.05$; present) or not detected (absent). To enable comparison between chips, the data were scaled to a global intensity of 500. The Data Mining Tool 2.0 (Affymetrix, Inc.) and GeneSpring software package 7.2 (Silicon Genetics, Redwood City, CA) were used to average results from different samples and to perform statistical analyses.

\section{Tumor Samples}

Tissue samples of gastric cancer were obtained surgically between 1995 and 2008 at University Hospital Schleswig-Holstein. For immunohistochemical analyses, samples from 486 patients with gastric cancer (304 men and 182 women; mean age at diagnosis, 68 years) were used, comprising 187 intestinal and 218 diffuse carcinomas according to the Laurén classification. Forty-two patients demonstrated a mixed-type gastric cancer. Survival data were available for 374 patients. Follow-up data for the other patients was missing because they did not reside near the hospital or were lost to follow-up. Of 374 patients, 313 died during follow-up. Median follow-up for patients alive at the end of the study was 19 months. Only patients with histologically confirmed gastric cancer and adequate tissue available were included. The study was approved by the local ethics committee of University Hospital in Kiel, Germany (reference No. D 453/10). 


\section{Real-Time RT-PCR}

For RT-PCR analysis, fresh-frozen neoplastic and corresponding nonneoplastic tissue from 38 patients with intestinal gastric carcinoma (24 men and14 woman; mean [range] age, 67.1 [45 to 87] years) was obtained surgically between 1997 and 2009 at University Hospital Schleswig-Holstein (Germany) and between 1995 and 2008 at Charité University Hospital (Germany). Total RNA was isolated from cryoconserved tissues using the mirVana miRNA Isolation Kit followed by DNase treatment with the Turbo DNA-free kit (Ambion, Inc.). RNA quality was assessed in 1.5\% agarose gel. For cDNA synthesis, $2 \mu \mathrm{g}$ total RNA was reverse transcribed using the Transcriptor First Strand cDNA Synthesis Kit (Roche Diagnostics $\mathrm{GmbH}$, Mannheim, Germany). The genespecific primers were designed by Biomers.net $\mathrm{GmbH}$ (Ulm, Germany). Forward and reverse primer sequences, respectively, were as follows: FZD7, 5'-AAGCGGTTTGGATGAAAAGA-3' and 5'-GATTCACATCGC CGTTAT CA-3'; ADAM17, 5'-TCCTGGCATCATGTATCTGAAC-3' and 5'-GCAAGGACTGTTCCTGTCACT-3'; SDHA (homo sapiens succinate dehydrogenase complex, subunit $A$, flavoprotein), 5'-ATTTGGTGGACAGAGCCTCA-3' and 5'-CTGGTATCATATCGCAGAGACCT-3'; CAPN2 (homo sapiens calpain 2), 5'-CGCTGACCCCCAGTTTATC-3' and 5'-TCAAGGTGAGGGAGGCAAT-3'; and CYCC (cyclophilin C), 5'-GGAAAAGTCATTGATGGGATG-3' and 5'-CAAAAGGCGTTTTCACGTCTA-3'. Real-time RT-PCR was performed using the LightCyler 480 Probes Master and the LightCycler 480 System (Roche Diagnostics $\mathrm{GmbH}$ ). The comparative cycle threshold values were normalized to those of the three housekeeping genes: SDHA, CAPN2, and CYCC. No template controls (no CDNA in PCR) were run for each gene to detect nonspecific or genomic amplification and primer dimerization. All experiments were performed in duplicate.

\section{Histology}

For histologic analyses, tissue samples were fixed in 10\% neutralized formalin and embedded in paraffin. Deparaffinized sections were stained using H\&E. The pathologic TNM stage was determined according to UICC guidelines. ${ }^{11}$

\section{Tissue Microarray Construction}

FFPE tissue samples were used to generate tissue microarrays, as described previously. ${ }^{12}$ In brief, three morphologically representative regions of the paraffin "donor" blocks were chosen. Tissue cylinders $1.5 \mathrm{~mm}$ in diameter were punched from these areas and precisely arrayed into a new "recipient" paraffin block using a custom-built instrument (Beecher Instruments, Silver Spring, MD). After completing the block construction, 4- $\mu \mathrm{m}$ sections of the resulting tumor tissue microarray block were cut for further analysis.

\section{Immunohistochemistry}

Immunostaining was performed using a polyclonal antibody directed against ADAM17 (diluted 1:200; SigmaAldrich Corp.) and a polyclonal antibody directed against FZD7 (1:800; Aviva Systems Biology Corp., San Diego, CA). For immunohistochemistry, paraffin sections were dewaxed and rehydrated using xylol and a descending alcohol series. After antigen retrieval [sodium citrate $(\mathrm{pH}$ 6.0); 5 minutes; pressure cooker; ADAM17, FZD7], the sections were pretreated with an Ultra $\mathrm{V}$ Block (Thermo Scientific $\mathrm{GmbH}$, Schwerte, Germany) before antibody staining to minimize nonspecific staining reaction. Incubation with the primary antibodies was performed in a moist chamber at room temperature for 30 minutes (ADAM17) or 60 minutes (FZD7). Slides were washed between steps with Tris-Tween buffered saline solution. Immunoreactions were visualized with the UltraVisionAP Polymer Detection System (Thermo Scientific $\mathrm{GmbH}$ ) according to the manufacturer's instructions. Fast Red served as chromogen. The specimens were counterstained with hematoxylin. Omission of primary antibodies served as negative controls, and normal human colon (ADAM17) and kidney (FZD7) tissue served as positive controls.

\section{Evaluation of Staining of Tissue Slides}

Immunostaining of the tissue microarrays was evaluated by an experienced histopathologist (V.W.) with special interest in gastrointestinal pathology, and scored by applying an immunoreactivity scoring system (IRS). In brief, category A documented the intensity of immunostaining as 0 (no immunostaining), 1 (weak), 2 (moderate), and 3 (strong). Category B documented the percentage of immunoreactive cells as 0 (no immunoreactive cells), 1 ( $<10 \%$ ), 2 (10\% to $50 \%$ ), 3 (51\% to $80 \%$ ), and $4(>80 \%)$. Addition of category $A$ and $B$ resulted in an IRS ranging from 0 to 7 for each case. Cases with an IRS of 1 or higher were categorized as positive, and those with an IRS less than 1 were categorized as negative.

\section{Statistical Analyses}

Real-time RT-PCR data were logarithmized to obtain approximately normally distributed data. Results were evaluated with a paired two-sided $t$-test. $P<0.05$ was considered statistically significant.

The significance of associations between ADAM17 and FZD7 immunostaining patterns and clinicopathologic patient characteristics was tested using the Mann-Whitney test or the Fisher exact test. The probability of differences in overall survival as a function of time was determined using the Kaplan-Meier method, with a log-rank test for significance. Multiple survival analysis was performed using Cox regression and subsequent backward selection. Statistical decisions were made two-tailed with a critical probability of $\alpha=5 \%$ without $\alpha$-adjustment, and $P$ values supported the interpretation. Thus, the results should be interpreted as 
A

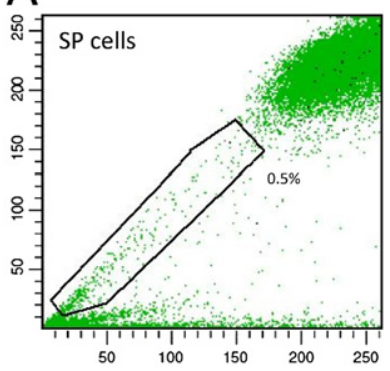

C

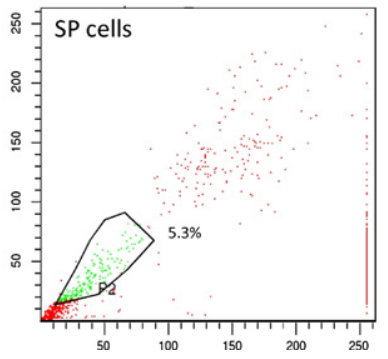

B

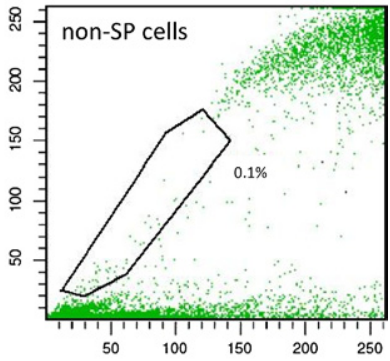

$\mathrm{D}$

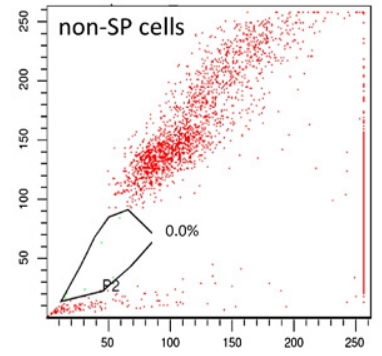

Figure 1. A side population can be differentiated at FACS analysis even after recultivation. AGS cells were stained with Hoechst 33342 and displayed in a Hoechst red (horizontal axis) versus Hoechst blue (vertical axis) diagram before $(\mathbf{A}$ and $\mathbf{B})$ and after $(\mathbf{C}$ and $\mathbf{D})$ recultivation for 6 days and a second FACS analysis. The SP region contains $0.5 \%$ and $5.3 \%$ of the cells, respectively, defined by gate P2 at the lower left (A and C), whereas this characteristically low staining pattern disappears in the presence of verapamil: $0.1 \%$ and $0.0 \%$ of cells, respectively (B and $\mathbf{D})$.

exploratory. All statistical analyses were performed using commercially available software (SPSS version 18.0; SPSS, Inc., Chicago, IL).

\section{Results}

\section{Hoechst 33342 Staining Does Not Affect Cell Viability}

Hoechst 33342 is cytotoxic, ${ }^{13}$ and the first set of experiments tested the viability of the cells after incubation with different final concentrations of the Hoechst dye and subsequent FACS analysis. Neither incubation of gastric cancer cells with 2.0 to $10.0 \mu \mathrm{g} / \mathrm{mL}$ Hoechst 33342 culture medium nor subsequent FACS analyses affected cell viability (see Supplemental Figure S1 at http://ajp.amjpathol.org).

\section{SPs Can Be Separated Reproducibly from Gastric Cancer Cell Lines Using Hoechst 33342 Staining and FACS Analysis}

Use of Hoechst 33342 staining and subsequent FACS analysis enabled reproducible isolation of an SP from both gastric cancer cell lines, AGS and MKN45. The SP cells demonstrated lower dye uptake as they effluxed Hoechst 33342 via ABC transporters. Dead cells were identified using the sample gate. Only a few dead or damaged cells were observed, which illustrates the low cytotoxicity of the experimental procedure. The SP cells were identified using verapamil, which blocks the

ABC transporters. SP cells were defined as the subset of cells that exhibited a low Hoechst 33342 staining pattern and disappeared with use of verapamil. In preceding experiments, a concentration of $5 \mu \mathrm{g} / \mathrm{mL}$ Hoechst dye was determined to be the optimal final concentration (data not shown). This was consistent with subsequent concentration assays and with previous reports by others. ${ }^{10}$ Higher final concentrations increased the background fluorescence and prohibited the analysis, whereas concentrations less than 5 $\mu \mathrm{g} / \mathrm{mL}$ decreased sensitivity and impaired identification of SP cells. The harvested cells were fully suitable for FACS analysis, generating a characteristic image in the Hoechst blue versus Hoechst red diagram (Figure 1), similar to that described by others. ${ }^{14,15}$

A total of 23 sortings were performed, of which 16 were with AGS cells and 7 with MKN45 cells. The overall percentage of SP cells within the cell cultures was comparable between the two cell lines, and ranged from $0.1 \%$ to $0.8 \%$.

\section{SP Cells Self-Renew in Cell Culture and Differentiate into SP Cells and Non-SP Cells}

In the next set of experiments, the ability of SP and non-SP cells to reculture in vitro was examined. SP and non-SP cells were separated via FACS and recultured under the same conditions. Recultivation experiments were performed six times with AGS and twice with MKN45. Both cell populations grew in culture again, and were subjected to a second round of Hoechst 33342 staining and FACS analysis after 6 to 10 days of recultivation. Recultured SP cells generated both SP and non-SP cells, whereas recultured non-SP cells generated primarily non-SP cells. The fraction of SP cells in the recultured SP population was higher than in the initial population (up to 5.3\%). However, the percentage of SP cells in the recultured cells decreased over time; on day 6 , the number of SP cells was $5.3 \%$, and on day 10 , the number of SP cells had decreased to $0.2 \%$ of all cells. Thus, SP cells were able to reestablish a population consisting of SP and non-SP cells within 10 days of recultivation. Non-SP cells did not demonstrate this capability (Figure 1; Table 1).

Table 1. SP Cells Self-Renew in Cell Culture

\begin{tabular}{|c|c|c|c|c|}
\hline $\begin{array}{l}\text { Time between first and second } \\
\text { FACS analyses (recultivation } \\
\text { time), day }\end{array}$ & 6 & 7 & 9 & 10 \\
\hline SP fraction after first sorting, \% & 0.2 & 0.2 & 0.1 & 0.1 \\
\hline $\begin{array}{l}\text { Reanalysis of SP fraction after } \\
\text { recultivation of SP cells, \% }\end{array}$ & 5.3 & 2.1 & 0.8 & 0.2 \\
\hline $\begin{array}{l}\text { Reanalysis of SP fraction after } \\
\text { recultivation of non-SP cells, \% }\end{array}$ & 0.0 & 0.0 & 0.1 & 0.1 \\
\hline
\end{tabular}




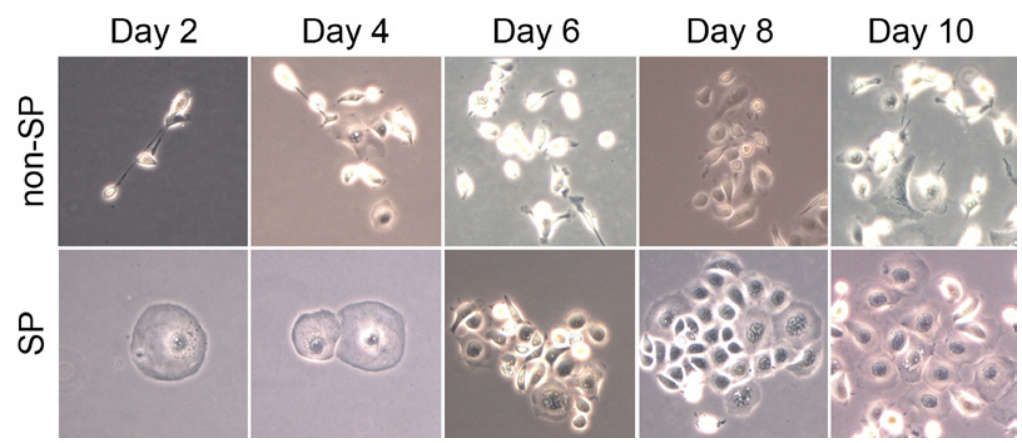

Figure 2. Recultured SP and non-SP cells exhibit different growth patterns. After FACS analysis of AGS cells, SP and non-SP cells were recultivated and photographed every other day. SP cells formed circular colonies starting from single clusters of round SP cells. Non-SP cells demonstrated more fibroblastlike morphologic features and formed loose groups of slightly pleomorphic cells. Original magnification: $\times 200$.

\section{Growth Pattern of Recultured Cells Varies between SP and Non-SP Cells Insofar as Cell Shape and Colony Formation}

Cell growth and colony formation were monitored daily with a microscope, and demonstrated that SP and non-SP cells exhibit different growth patterns. Recultivated SP cells settled as round cells on the bottom of the cell culture flask within one day. In the following days, they formed circular colonies, which finally merged and enclosed cells of different shape and size. Non-SP cells settled with a more fibroblastlike cell shape and formed loose, disorganized, discohesive colonies (Figure 2).

\section{Phenotyping of SP and Non-SP Cells}

In the next set of experiments, the phenotype of SP cells embedded in agarose (MKN45) or cytocentrifuged onto glass slides (AGS) was studied using H\&E staining and immunocytochemistry. The isolated SP cells were smaller and rounder than the non-SP cells. This difference was more distinct for AGS cells than for MKN45 cells (Figure 3 ). This might be due to the different techniques of fixation. The embedding in agarose and conventional cutting using a microtome might have resulted in more angular MKN45 cells compared with the cytocentrifugation and fixation of AGS cells on glass slides, in which the cells became round. Despite the different techniques, a similar difference was observed in both cell lines.

For immunophenotyping, different techniques were tested. FACS analysis was impossible because the fluorescence signal of phycoerythrin- and propidium iodidecoupled antibodies interfered with each other and with the Hoechst labeling. In addition, detection of intracellular targets was not reproducible (data not shown). Therefore, immunophenotyping was performed at immunocytochemistry. Five different target proteins were selected, which were previously demonstrated to identify stem cells, that is, CD44, ${ }^{5} \mathrm{CD} 117,{ }^{16} \mathrm{CD} 133,{ }^{17}$ LGR5, ${ }^{18}$ and MSI-1. ${ }^{19,20}$ Cytoplasmic staining was observed for CD44, CD117, CD133, LGR5, and FZD7. A membranous immunoreaction was observed for CD133 and LGR5. Staining was then evaluated by counting a total of at least 80 cells in two separate high-power fields. For both cell lines, the number of CD133- and MSI-1-immunoreactive cells was higher in the SP fraction compared with the non-SP frac- tion. CD44 was more prevalent in the SP fraction of AGS cells, and less commonly in the SP fraction of MKN45 cells. CD117 and LGR5 did not differentiate SP from non-SP cells in either cell line (Figure 4; Supplemental Table S1 at $h$ ttp://ajp.amjpathol.org).

\section{Gene Array}

The SP on the transcriptional level was characterized using AGS cells only. mRNA was extracted and forwarded to gene array analysis from four separate experiments of Hoechst-staining and FACS and from two unsorted cell lines generating 10 gene array data sets: four sets from SP cells (SP a to SP-d), four sets from non-SP cells (non-SP-a to non-SP-d), and two sets from the unsorted cell population (UCP-a and UCP-b). The data sets obtained from the 10 arrays were normalized to account for variability in hybridization for probe pairs and other hybridization artifacts. For normalization, the first step compared the gene array data of two experiments: SP-a versus SP b,

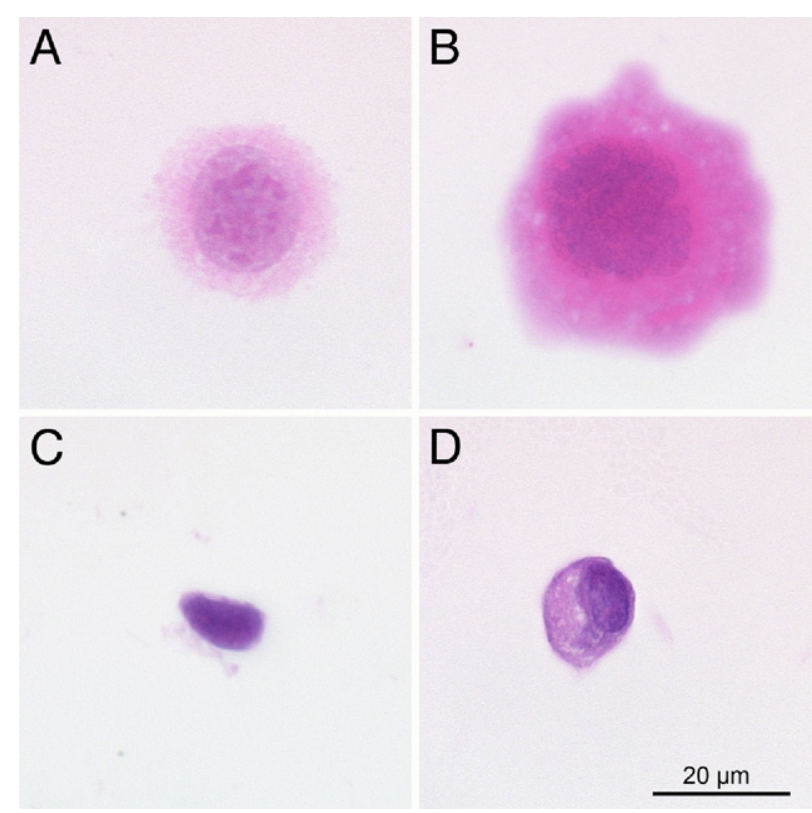

Figure 3. SP and non-SP cells demonstrate cytologically different phenotypes. Cells cytocentrifuged onto glass slides (AGS; $\mathbf{A}$ and $\mathbf{B}$ ) and cells embedded in agarose (MKN45; $\mathbf{C}$ and $\mathbf{D}$ ) were stained with H\&E and demonstrated different phenotypes of SP cells (A and $\mathbf{C})$ and non-SP cells (B and D). Original magnification: $\times 400(\mathbf{A}-\mathbf{D})$. 


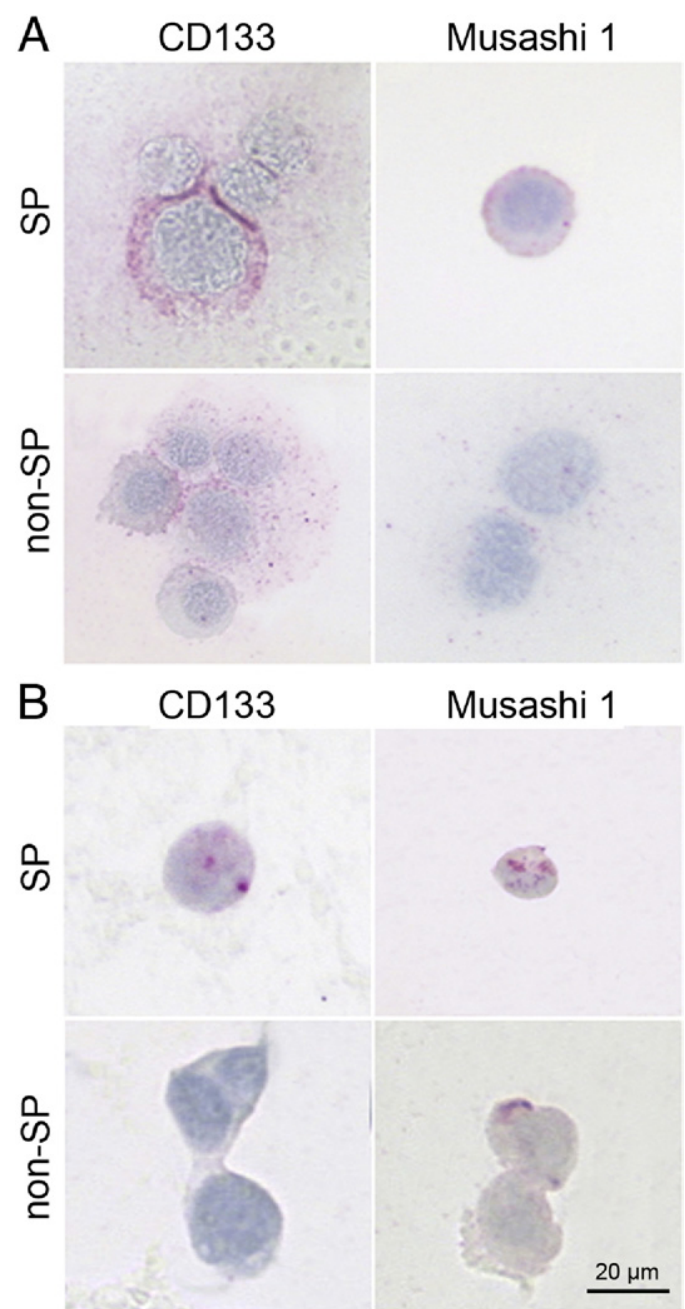

Figure 4. SP and non-SP cells demonstrate different immunophenotypes. Expression of various putative stem cell markers was studied at immunocytochemistry. For AGS (A) and MKN45 (B) cells, the number of CD133- and Musashi-1 immunoreactive cells was significantly different. Immunostaining was with anti-CD133 and anti-Musashi-1 antibodies. Hematoxylin counterstain. Original magnification: $\times 400(\mathbf{A}$ and $\mathbf{B})$.

SP-c versus SP-d, non-SP-a versus non-SP-b, non-SP-c versus non-SP-d, and UCP-a vs UCP-b (see Supplemental Figure S2 at http://ajp.amjpathol.org). As shown in Figure S2, 40649 to 44542 genes were identified, which were commonly expressed in SP, non-SP, and UCP cells (fold change factor $<1.5$ ), respectively. The second step identified genes that were up-regulated or down-regulated (fold change factor >1.5), and differentiated SP and non-SP cells from UCP cells, and SP from non-SP cells. Between 4806 and 6908 differentially expressed genes differentiate non-SP from UCP cells, between 2804 and 4292 differentiated SP from UCP cells, and between 1391 and 3124 differentiated SP from non-SP cells. The third step searched for genes that were commonly up-regulated and down-regulated in SP cells. Finally identified were 531 genes that were up-regulated ( $n=172)$ or down-regulated $(n=359)$ in four separate SP cell preparations, and SP cells were differentiated from non-SP cells (see Supplemental Table S2 at $h$ ttp://ajp. amjpathol.org).

\section{Genes Differentially Expressed in SP Cells Are Also Expressed in Gastric Cancer Tissue}

The next set of experiments were performed to prove on the transcriptional and translational levels whether some of the 172 genes differentially expressed and up-regulated in SP cells are also detectable in human gastric cancer tissue. Previous studies provided evidence that $G$ protein-coupled receptors and the Notch, ${ }^{21-23}$ sonic hedgehog $(\mathrm{SHH}),{ }^{24-26} \mathrm{WNT},{ }^{27,28}$ and FGF signaling pathways $^{29}$ have an important role in stem cell biology and might also be crucial for the role of stem cells in tumor biology. Data sets were searched for genes of these pathways that differentiate SP cells from non-SP and UCP cells. Identified were 10 genes of the SP, which were G protein-coupled receptors (GNAS, SMO, YY1, S1PR3, and GPR161) and/or members of the Notch (ADAM17 and Hey1), WNT (FZD7 and FOSL1), or FGF (FGFR2) signaling pathways. Antibodies for immunohistochemistry were commercially available for two of these genes (ADAM17 and FZD7), and were used to test their expression in nonneoplastic gastric mucosa and gastric cancer tissue.

Both ADAM17 and FZD7 were expressed in the human stomach (Figures 5 and 6). In the nonneoplastic mucosa, ADAM17 was observed in a few scattered cells of the gastric glands (Figure 5), whereas FZD7 was observed almost exclusively in inflammatory cells. The foveolar epithelium expressed neither ADAM17 nor FZD7. Both were observed in epithelial cells at the base of the intestinal metaplasia, whereas cells farther up in the metaplastic foveolae lost ADAM17 and FZD7 expression (Figure 6). ADAM17 and FZD7 were also expressed in gastric cancer cells (Figure 6). Immunostaining was observed in the cytoplasm and occasionally at the cell membrane. Using tissue microarrays, ADAM17-positive (IRS $\geq 1$ ) gastric carcinomas were observed in 123 cases (26\%), and FZD7-positive (IRS $\geq 1$ ) carcinomas in 162 cases (34\%). The expression of FZD7 correlated highly significantly with tumor type $(P=0.005)$ and expression of ADAM17 $(P<0.001$; Table 2). However, no further correlation was found between expression of either ADAM17 or FZD7 and local tumor growth ( $T$ category), nodal spread ( $\mathrm{N}$ category), tumor stage, and tumor grade (Table 2).

The correlation between various clinicopathologic patient characteristics and patient survival was studied. To assess the influence of ADAM17 and FZD7 expression and patient survival, immunostaining was dichotomized using the median of the expression of ADAM17 and FZD7. Cancers with an IRS less than the median value $(\mathrm{IRS}=0)$ were categorized as ADAM17- or FZD7-negative, and cancers with an IRS equal to or greater than the median value (IRS $\geq 1$ ) were categorized as ADAM17- or FZD7-positive. Patient survival correlated significantly with local tumor growth (T category; $P<0.001$ ), nodal spread ( $N$ category; $P<0.001)$, tumor stage $(P<$ $0.001)$, and tumor grade $(P<0.001$; Table 3$)$. FZD7immunopositive cancers demonstrated a significantly 
shorter median survival time (10.3 versus 13.4 months; Table 3; Figure 7).

The differential expression of ADAM17 and FZD7 mRNA was validated using real-time RT-PCR in an independent set of 38 intestinal-type gastric carcinoma samples. Nonneoplastic mucosa was compared with the primary tumor. ADAM17 expression was highly significantly increased in gastric carcinoma compared with nonneoplastic mucosa $(P<0.001)$. There was no significant difference in FZD7 expression in gastric carcinoma vs nonneoplastic mucosa $(P=0.448)$ at the transcriptional level. However, this lack of difference was related to expression of FZD7 in inflammatory cells in both the nonneoplastic and neoplastic compartment (Figure 8).
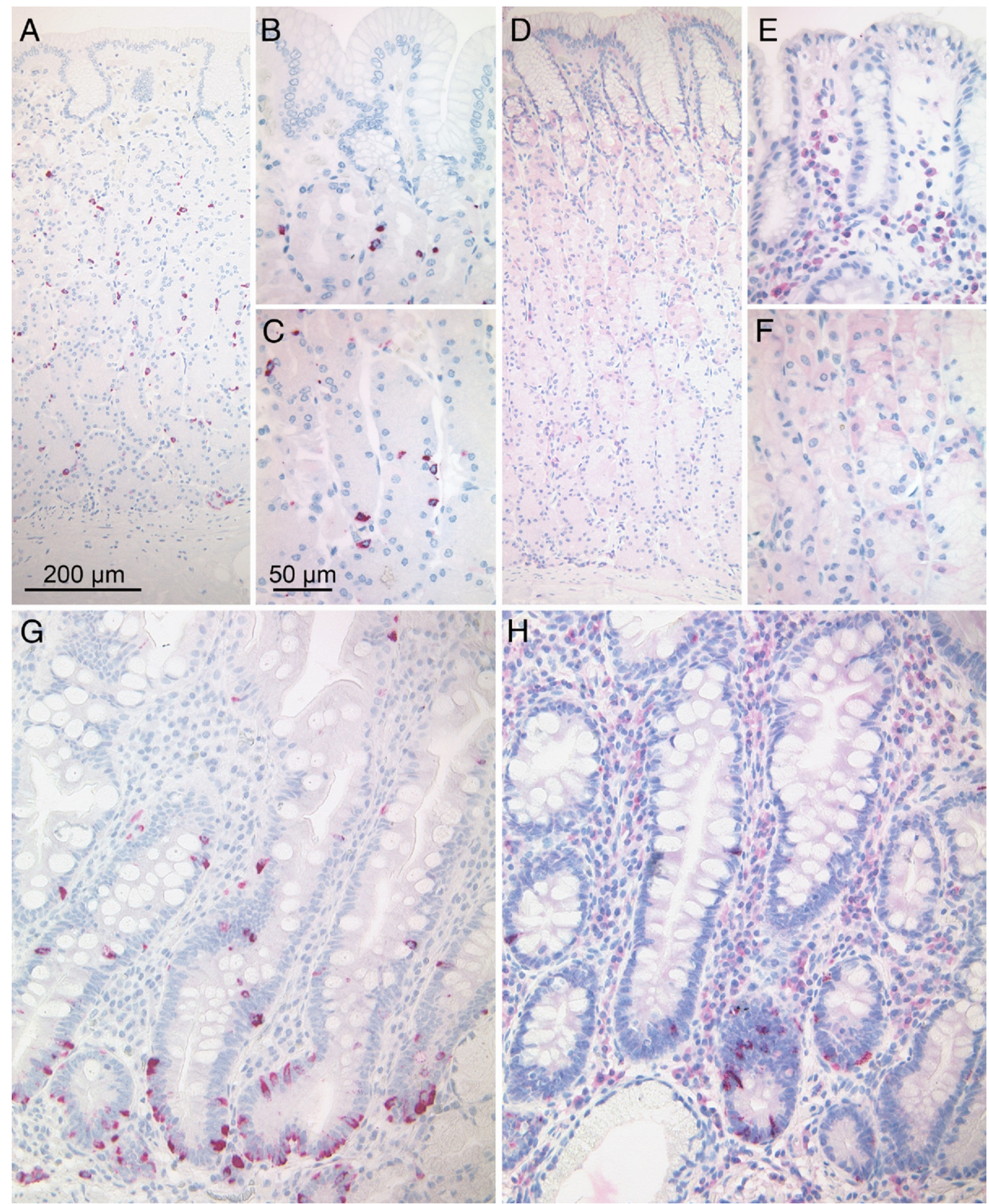

Figure 5. Expression of ADAM17 and FZD7 in nonneoplastic gastric tissue. A, B, C, and G: Expression of ADAM17. D, E, F, and H: Expression of FZD7. Foveolar epithelium did not express ADAM17 (B) or FZD7 (E). ADAM17 was observed in a few scattered cells of the gastric glands (C). FZD7 was expressed in inflammatory cells of the lamina propria (E), whereas the gland epithelium was immunonegative (F). ADAM17 (G) and FZD7 (H) were also expressed in bottom cells of the intestinal metaplasia. Hematoxylin counterstain. Original magnification: $\times 100(\mathbf{A}, \mathbf{D}, \mathbf{G}$, and $\mathbf{H}) ; \times 400(\mathbf{B}, \mathbf{C}, \mathbf{E}$, and $\mathbf{F})$. 


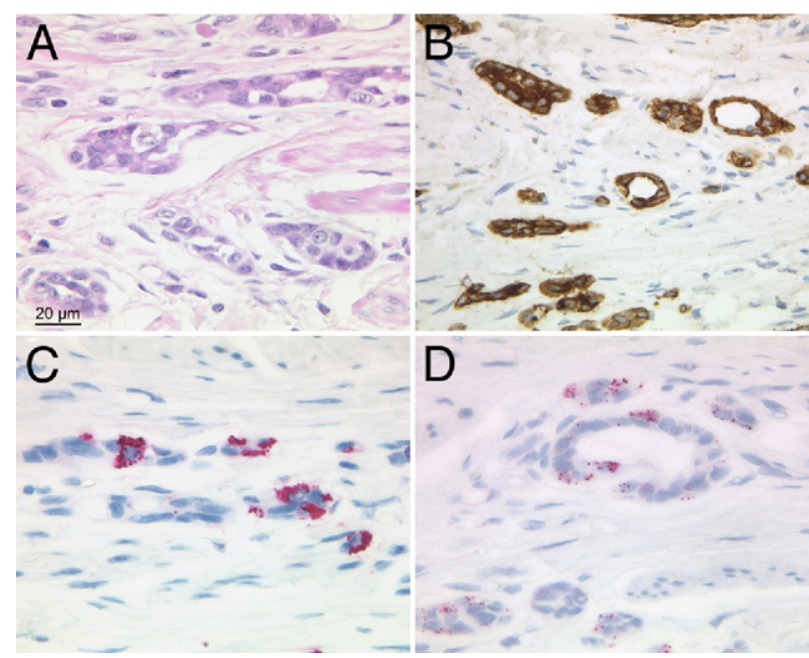

Figure 6. Expression of ADAM17 and FZD7 in gastric cancer tissue. ADAM17 and FZD7 are expressed in intestinal-type gastric cancer cells. All images are from the same case. H\&E (A), pan-cytokeratin (B), ADAM17 (C), and FZD7 (D). Hematoxylin counterstain. Original magnification: $\times 600$ (A-D)

\section{Discussion}

Despite seemingly complete resection of gastric cancer (RO) via gastrectomy and subsequent chemotherapy, most patients with gastric cancer die of the disease. Clearly, gastric cancer in most instances has already spread to distant sites when local resection is performed, and a substantial number of metastatic cancer cells are resistant to chemotherapy. If patient outcome is to be improved, a treatment must be developed that specifically targets those hidden chemotherapy-resistant tumor cells. ${ }^{3}$ Identification of tumor cells with intrinsic resistance against chemotherapy would provide valuable information for improved cancer therapy. The SP model used in the present study is an interesting model because SP cells express high levels of $\mathrm{ABC}$ transporters. It was hypothesized that tumor recurrence is caused by CSCs, which are rich in $\mathrm{ABC}$ transporters, and that the SP of cancer cell lines shares characteristics with these CSCS. This study phenotypically and genotypically characterized the SP of two gastric cancer cell lines, AGS and MKN45. The SP cells were smaller, expressed CD133 and MSI-1, and generated SP and non-SP cells in recultivation experiments.

Table 2. Correlation of Expression of ADAM17 and FZD7 With Various Clinicopathologic Patient Characteristics

\begin{tabular}{|c|c|c|c|c|c|c|}
\hline \multirow[b]{2}{*}{ Variable } & \multicolumn{3}{|c|}{ ADAM17 } & \multicolumn{3}{|c|}{ FZD7 } \\
\hline & Negative & Positive & $P$ value* & Negative & Positive & $P$ value* \\
\hline Sex & & & 0.668 & & & 0.161 \\
\hline Male & $214(73)$ & $81(27)$ & & $182(62)$ & $111(38)$ & \\
\hline Female & $133(75)$ & $45(25)$ & & $120(69)$ & $54(31)$ & \\
\hline Age, years & & & 0.723 & & & 0.125 \\
\hline$<68$ & $128(74)$ & $44(26)$ & & $117(68)$ & $55(32)$ & \\
\hline$\geq 68$ & $140(72)$ & $53(28)$ & & $113(60)$ & $76(40)$ & \\
\hline Pathologic tumor stage & & & 0.563 & & & 0.560 \\
\hline pT1 & $44(76)$ & $14(24)$ & & $33(75)$ & $13(25)$ & \\
\hline pT2 & $43(80)$ & $11(20)$ & & $33(60)$ & $22(40)$ & \\
\hline pT3 & $132(71)$ & $55(29)$ & & $119(63)$ & $71(37)$ & \\
\hline pT4 & $127(74)$ & $45(26)$ & & $111(50)$ & $58(34)$ & \\
\hline Nodal status & & & 0.525 & & & 0.627 \\
\hline pNO & $103(77)$ & $31(23)$ & & $86(66)$ & $45(34)$ & \\
\hline pN1 & $50(70)$ & $21(30)$ & & $39(56)$ & $31(44)$ & \\
\hline pN2 & $54(69)$ & $24(31)$ & & $51(67)$ & $25(33)$ & \\
\hline pN3 & $135(73)$ & $49(27)$ & & $122(66)$ & $63(34)$ & \\
\hline Tumor stage & & & 0.309 & & & 0.412 \\
\hline IA & $10(71)$ & $4(29)$ & & $9(69)$ & $4(31)$ & \\
\hline IB & $8(73)$ & $3(27)$ & & $10(91)$ & $1(9)$ & \\
\hline$\| A$ & $22(79)$ & $6(21)$ & & $13(48)$ & $14(52)$ & \\
\hline IIB & $20(74)$ & $7(26)$ & & $15(56)$ & $12(44)$ & \\
\hline IIIA & $29(78)$ & $8(22)$ & & $25(68)$ & $12(32)$ & \\
\hline IIIB & $46(70)$ & $20(30)$ & & $45(69)$ & $20(31)$ & \\
\hline IIIC & $45(85)$ & $8(15)$ & & 37 (69) & $17(31)$ & \\
\hline IV & $42(63)$ & $25(37)$ & & $36(55)$ & $30(45)$ & \\
\hline Tumor grade & & & 0.467 & & & 0.308 \\
\hline G1/G2 & $81(70)$ & $34(30)$ & & $96(61)$ & $45(39)$ & \\
\hline $\mathrm{G} 3 / \mathrm{G} 4$ & $254(74)$ & $89(26)$ & & $223(66)$ & $114(34)$ & \\
\hline Laurén classification & & & 0.277 & & & 0.005 \\
\hline Intestinal & $128(71)$ & $52(29)$ & & $103(57)$ & $78(43)$ & \\
\hline Diffuse & $151(71)$ & $61(29)$ & & $150(73)$ & $57(27)$ & \\
\hline Mixed & $35(83)$ & $7(17)$ & & $25(61)$ & $16(39)$ & \\
\hline FZD7 & & & $<0.001$ & & & \\
\hline Negative (0) & $232(80)$ & $60(20)$ & & & & \\
\hline Positive $(>0)$ & $99(61)$ & $63(39)$ & & & & \\
\hline
\end{tabular}


Table 3. Patient Survival Related to Clinicopathologic Patient Characteristics

\begin{tabular}{|c|c|c|c|c|}
\hline Variable & No. of patients & No. of events & Survival, median (95\% Cl), mo & $P$ value* \\
\hline Sex & & & & 0.843 \\
\hline Male & 233 & 199 & $12.1(10.0-14.3)$ & \\
\hline Female & 140 & 113 & $12.6(9.5-15.6)$ & \\
\hline Age, years & & & & 0.338 \\
\hline$<68$ & 177 & 148 & $12.8(9.9-15.8)$ & \\
\hline$\geq 68$ & 196 & 164 & $12.1(10.2-14.0)$ & \\
\hline Pathologic tumor stage & & & & $<0.001^{\dagger}$ \\
\hline pT1 & 37 & 15 & $50.5(39.3-61.7)$ & \\
\hline рT2 & 34 & 24 & $21.9(0-45.4)$ & \\
\hline pT3 & 150 & 129 & $13.6(11.3-15.9)$ & \\
\hline pT4 & 151 & 143 & $8.3(5.7-10.9)$ & \\
\hline Nodal status & & & & $<0.001^{\dagger}$ \\
\hline pNO & 82 & 48 & $34.7(25.3-44.1)$ & \\
\hline pN1 & 52 & 43 & $15.5(10.6-20.4)$ & \\
\hline pN2 & 69 & 61 & $16.4(12.1-20.7)$ & \\
\hline pN3 & 166 & 156 & $8.0(6.1-9.8)$ & \\
\hline Tumor stage & & & & $<0.001^{\dagger}$ \\
\hline IA & 13 & 11 & $50(0-103)$ & \\
\hline IB & 11 & 9 & $13(0-27)$ & \\
\hline$\| A$ & 28 & 28 & $15.5(0-35.2)$ & \\
\hline IIB & 26 & 26 & $15.5(9.1-21.9)$ & \\
\hline IIIA & 36 & 36 & $12.1(9.0-15.2)$ & \\
\hline IIIB & 67 & 67 & $12.6(9.9-15.3)$ & \\
\hline IIIC & 54 & 54 & $4.8(0.3-9.3)$ & \\
\hline IV & 69 & 69 & $6.4(4.5-8.4)$ & \\
\hline Tumor grade & & & & $<0.001$ \\
\hline $\mathrm{G} 1 / \mathrm{G} 2$ & 83 & 60 & $24.5(14.3-34.7)$ & \\
\hline G3/G4 & 278 & 243 & $11.1(9.2-13.0)$ & \\
\hline Laurén classification & & & & $0.052^{\dagger}$ \\
\hline Intestinal & 136 & 113 & $14.7(10.2-19.1)$ & \\
\hline Diffuse & 173 & 147 & $11.1(8.8-13.5)$ & \\
\hline Mixed & 36 & 29 & $9.4(5.7-13.1)$ & \\
\hline ADAM17 & & & & 0.805 \\
\hline Negative & 267 & 225 & $12.1(10.3-13.9)$ & \\
\hline Positive & 97 & 82 & $12.7(9.2-16.3)$ & \\
\hline FZD7 & & & & 0.008 \\
\hline Negative & 229 & 190 & $13.4(10.9-15.8)$ & \\
\hline Positive & 131 & 113 & $10.3(7.6-12.9)$ & \\
\hline
\end{tabular}

$\mathrm{Cl}$, confidence interval.

*Log rank test.

tPooled over groups

CD133 is a cell surface protein with largely unknown function, which has five transmembrane domains. Since its discovery in 1997, CD133 has been studied extensively. ${ }^{30}$ CD133 is one of the most common markers of stem cells of different tissues, and also gains increasing importance as a marker for CSCs. Cells with stem cell properties in tumors of the central nervous system and epithelium demonstrate increased expression of CD133. ${ }^{17}$ Recently, doubt has been raised as to whether CD133 is a valuable marker for progenitor cells. Nishii et $\mathrm{al}^{31}$ detected decreased expression of CD133 in SP cells of gastric carcinoma, and concluded that CD133 might not be an appropriate marker of CSCs. Inasmuch as studies vary substantially insofar as the cell lines used and experiment setup, it is problematic to draw a final conclusion about CD133 expression and "stemness" of cells. The RNA binding protein MSI-1 was first described in Drosophila, in which it enables two subsequent asymmetric cell divisions. MSI-1 can be detected in neuronal progenitor cells. These undifferentiated cells show a high proliferation rate and generate a variety of cells including astrocytes, neurons, and oligodendrocytes.
MSI-1 was also observed in intestinal crypts, which are the niche of intestinal stem cells. ${ }^{19}$ Not only is MSI-1 expressed in the colon epithelium of newborn mice, and this expression decreases over the lifetime, ${ }^{20}$ a recent in vitro study in intestinal epithelium primary cultures also demonstrated that MSI-1 overexpression promotes progenitor proliferation through induction of both the WNT and Notch pathways. ${ }^{32}$ In the present study, the number of CD133- and MSI-1-positive cells was significantly higher in SP cells than in non-SP cells in both cell lines, which suggests that CD133 and MSI-1 may be gastric CSC markers.

The potential role of CD44-positive cells in tumorigenicity was recently discussed, especially in gastric cancer. Takaishi et al ${ }^{5}$ observed high cancer-initiating potential and increased chemoresistance in CD44-positive cells of gastric cancer cell lines. In the present study, the association between CD44 expression and SP cells could not be reproducibly proved. SP cells of the AGS cell line demonstrated increased expression of CD44, whereas SP cells of the MKN45 cell line seemed to express less CD44. This indicates that CD44 is variably 


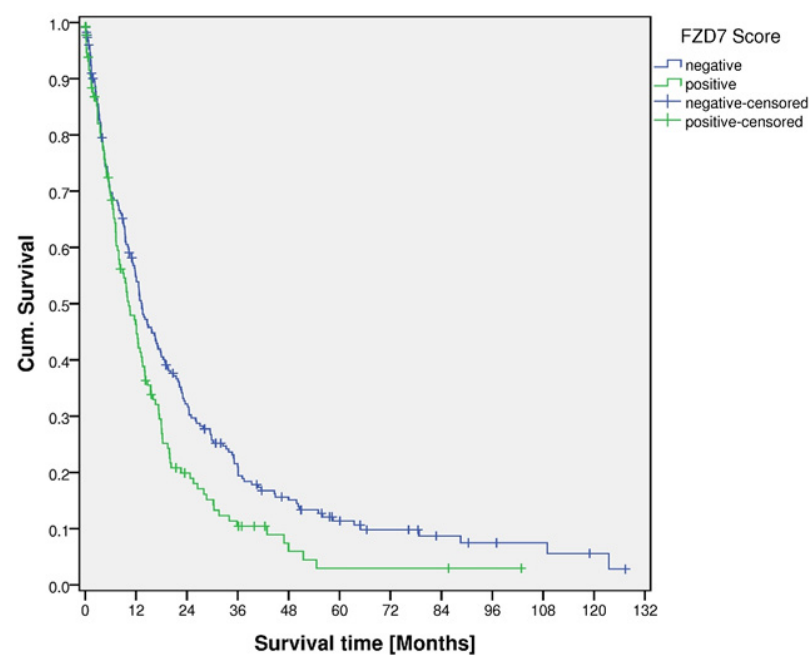

Figure 7. Overall survival in dependence of FZD7-expression. Kaplan-Meier curves depict overall survival in dependence of FZD7-expression in gastric cancer. The $P$ value was calculated using the log-rank test.

expressed between different gastric cancer cell lines and might not be a suitable marker to identify CSCs in all gastric cancers. This finding is supported in that only three of six examined gastric cancer cell lines had a sizable subpopulation of CD44-positive cells in the study by Takaishi et al. ${ }^{5}$

CD117 and LGR5, which were also considered stem cell markers, failed to discriminate between SP and non-SP cells. CD117 was primarily described as a marker of hematopoietic stem cells, and is also expressed in mast cells and gastrointestinal stromal tumors. Lack of expression in gastric SP cells provides evidence that CSCs may have organ- or tissue-specific expression profiles. LGR5 was recently introduced as a stem cell marker of the intestine. However, LGR was strongly expressed in SP and non-SP cells of both cell lines, and may be unsuitable as a marker for gastric CSCs.

SP and non-SP cells were then studied in cell culture experiments. After Hoechst staining and FACS analysis, SP and non-SP cells were recultured. The growth patterns of recultured SP and non-SP cells were different, which illustrates that these are distinct cell populations insofar as cell size and shape, immunophenotype (CD133-positive and MSI-1-positive), and growth pattern. Recultured SP cells were also able to generate both SP and non-SP cells. The number of SP cells was higher in recultured cells than in the basic population. This enrichment of SP cells was previously described by Haraguchi et $\mathrm{al}^{33}$ and provides evidence for their ability to self-renew and differentiate, which are basic characteristics of stem cells.

After phenotypic characterization, SP cells were studied on the transcriptional level. Overall, SP cells were characterized by the differential expression of 531 genes, with 172 up-regulated and 359 down-regulated. Previous studies provided evidence that the Notch, ${ }^{21-23} \mathrm{SHH}^{24-26}$ and WNT signaling pathways ${ }^{27,28}$ have an important role in stem cell biology and might also be crucial to the role of stem cells in tumor biology. The Notch pathway inhibits the differentiation of progenitor cells, helps to maintain stem cell properties, and is often deregulated in malignant tumors. ${ }^{34}$ ADAM 17 and HEY1 are part of this pathway and are overexpressed in SP cells. The putative role of ADAM17 in cancer biology was supported by observations in brain tumors. The expression of ADAM17 in brain tumors correlates with tumor cell invasion and is linked to activation of the epidermal growth factor receptor. ${ }^{35}$ In the present study, significant up-regulation of ADAM17 was observed on the transcriptional and translational levels in gastric cancer tissue, whereas no correlation was found between ADAM17 expression and any clinicopathologic patient characteristics. Thus, the putative tumor biological function of ADAM17 remains unclear. Despite this lack of correlation, ADAM17 was expressed by cells at the base of intestinal metaplasia
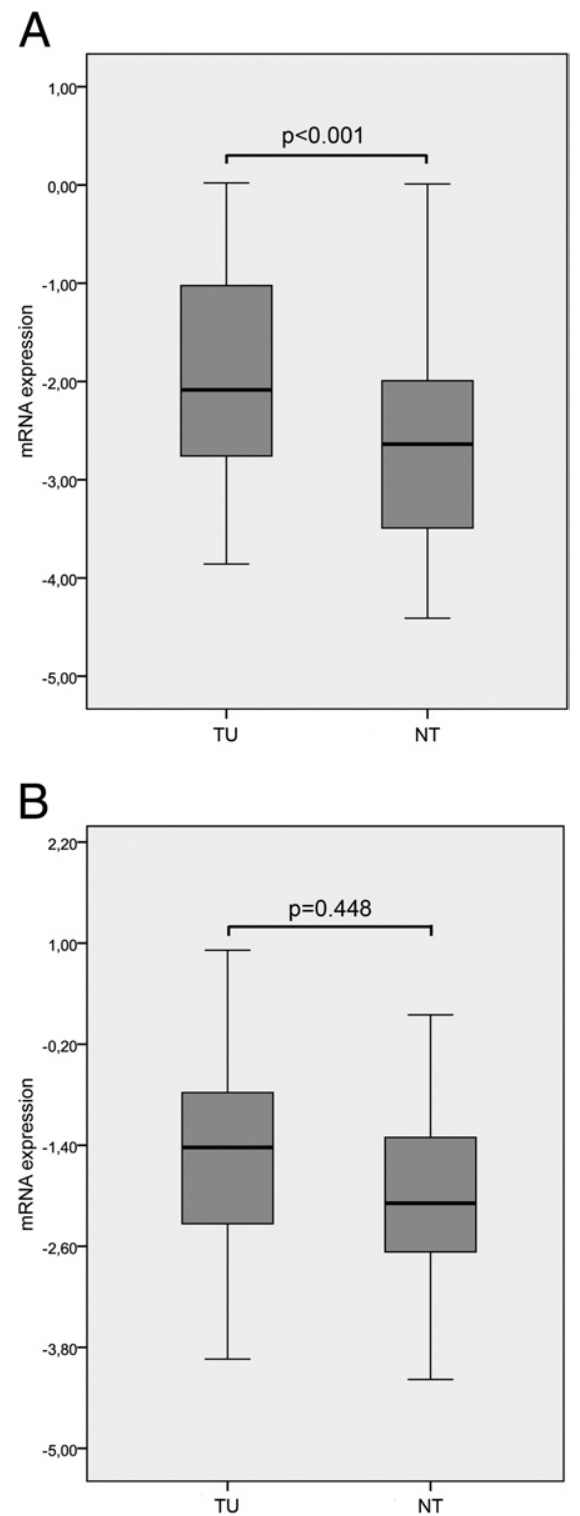

Figure 8. mRNA expression of ADAM17 and FZD7 in gastric tissue. A: ADAM17 mRNA is highly significantly up-regulated in gastric carcinoma compared with nonneoplastic mucosa $(P<0.001)$. B: FZD7 mRNA was slightly but not significantly increased in gastric cancer tissue compared with nonneoplastic mucosa $(P=0.448)$ 
without intracellular mucous formation, and was absent farther up in the metaplastic foveolae. This observation supports the contention that expression of ADAM17 is coupled with differentiation in the stomach mucosa.

HEY1 inhibits the transcription of tissue-specific transcription factors. This process is regulated by the RNA binding protein MSI-1. Similar observations indicating an association between expression of HEY1 and inhibition of differentiation of stem cells have been made in progenitor cells of the brain and mesenchymal stem cells. ${ }^{36,37}$

The WNT-pathway is also active in stem cells, preserves stem cell characteristics, and leads to accumulation of stem cells. Activation of the WNT pathway starts with linkage of the ligand to the FZD7 receptor, which was overexpressed in all four analyzed SP samples. In accordance with our findings, Mitsutake et a ${ }^{38}$ also observed up-regulation of HEY1 and FZD7 in SP cells. Various studies have demonstrated expression and significant up-regulation of FZD7 in embryonic stem cells compared with differentiated cells. ${ }^{39,40}$ FZD7 knock-out embryonic cell lines show a significant change in morphologic features and the surface marker pattern of stem cells. FOSL1 is another gene of the WNT pathway that was up regulated in SP cells. FOSL1 encodes for the leucine zipper protein that builds transcriptional factors with proteins of the June family. They regulate proliferation of cells and have a negative effect on the differentiation of progenitor cells. In the present study, expression of FZD7-in gastric cancer correlated significantly with patient survival. In addition, and similar to ADAM17, FZD7 was also expressed by cells at the base of the intestinal metaplasia, and FZD7 immunoreactivity in cancer cells correlated with ADAM17 immunoreactivity. All of these observations lend support to the hypothesis that both ADAM17 and FZD7 are differentiation markers in gastric tissue and that FZD7 might also be a novel putative prognostic marker by having an influence on disease progression. Further investigations into this topic are warranted.

Another interesting pathway is the $\mathrm{SSH}$. The integral membrane protein smoothened (SMO) is an important member of this pathway, and was up-regulated in SP cells. In general, an increased proliferation rate was observed in cells with an activated SSH pathway. Smoothened inhibitors and anti-SSH antibodies are used as chemotherapeutic agents in cancers with activation of the SSH pathway, and have shown promising results. ${ }^{41} \mathrm{SSH}$ also has a role in regeneration of inflamed gastric mucosa in patients with chronic infection with Helicobacter pylori. ${ }^{42}$

In summary, the present study provides evidence that $\mathrm{SP}$ cells can be reproducibly generated from human gastric cancer cell lines. SP cells are distinct insofar as cell morphologic features, growth pattern, immunophenotype, and genotype. Members of the signaling pathways Notch, SHH, and WNT, which have previously been shown to have major roles in tumor cell biology and stem cell biology, are differentially expressed in SP cells. Furthermore, genes differentially expressed in SP cells are also expressed by gastric cancer cells, and have a relationship with patient prognosis.

\section{Acknowledgments}

We thank Drs. Ute Ungethüm and Ralf Kuban (Laboratory of Functional Genomics, Charité University Hospital, Berlin, Germany) for technical assistance in gene array hybridization and data analysis, and Dr. Amke Caliebe for advice in statistical analyses.

\section{References}

1. Paoletti X, Oba K, Burzykowski T, Michiels S, Ohashi Y, Pignon JP Rougier P, Sakamoto J, Sargent D, Sasako M, Van Cutsem E, Buyse M: Benefit of adjuvant chemotherapy for resectable gastric cancer: a meta-analysis. JAMA 2010, 303:1729-1737

2. Al-Hajj M, Wicha MS, Benito-Hernandez A, Morrison SJ, Clarke MF: Prospective identification of tumorigenic breast cancer cells. Proc Natl Acad Sci USA 2003, 100:3983-3988

3. Frank NY, Schatton T, Frank MH: The therapeutic promise of the cancer stem cell concept. J Clin Invest 2010, 120:41-50

4. Todaro M, Francipane MG, Medema JP, Stassi G: Colon cancer stem cells: promise of targeted therapy. Gastroenterology 2010, 138:2151-2162

5. Takaishi S, Okumura T, Tu S, Wang SS, Shibata W, Vigneshwaran R, Gordon SA, Shimada Y, Wang TC: Identification of gastric cancer stem cells using the cell surface marker CD44. Stem Cells 2009 27:1006-1020

6. Goodell MA, Brose K, Paradis G, Conner AS, Mulligan RC: Isolation and functional properties of murine hematopoietic stem cells that are replicating in vivo. J Exp Med 1996, 183:1797-1806

7. Wulf GG, Wang RY, Kuehnle I, Weidner D, Marini F, Brenner MK, Andreeff M, Goodell MA: A leukemic stem cell with intrinsic drug efflux capacity in acute myeloid leukemia. Blood 2001, 98:1166-1173

8. Hirschmann-Jax C, Foster AE, Wulf GG, Nuchtern JG, Jax TW, Gobel U, Goodell MA, Brenner MK: A distinct "side population" of cells with high drug efflux capacity in human tumor cells. Proc Natl Acad Sci USA 2004, 101:14228-14233

9. Zhou S, Schuetz JD, Bunting KD, Colapietro AM, Sampath J, Morris JJ, Lagutina I, Grosveld GC, Osawa M, Nakauchi H, Sorrentino BP: The ABC transporter Bcrp1/ABCG2 is expressed in a wide variety of stem cells and is a molecular determinant of the side-population phenotype. Nat Med 2001, 7:1028-1034

10. Lin KK, Goodell MA: Purification of hematopoietic stem cells using the side population. Methods Enzymol 2006, 420:255-264

11. Sobin LH, Gospodarowicz MK, Wittekind Ch (Eds). TNM Classification of Malignant Tumors, 7th ed. Oxford, England, Wiley-Blackwell, 2009

12. Weichert W, Röske A, Gekeler V, Beckers T, Ebert MP, Pross M, Dietel M, Denkert C, Röcken C: Association of patterns of class I histone deacetylase expression with patient prognosis in gastric cancer: a retrospective analysis. Lancet Oncol 2008, 9:139-148

13. Zhang X, Chen J, Davis B, Kiechle F: Hoechst 33342 induces apoptosis in HL-60 cells and inhibits topoisomerase I in vivo. Arch Pathol Lab Med 1999, 123:921-927

14. Iwatani H, Ito T, Imai E, Matsuzaki Y, Suzuki A, Yamato M, Okabe M, Hori M: Hematopoietic and nonhematopoietic potentials of Hoechst (low)/side population cells isolated from adult rat kidney. Kidney Int 2004, 65:1604-1614

15. Triel C, Vestergaard ME, Bolund L, Jensen TG, Jensen UB: Side population cells in human and mouse epidermis lack stem cell characteristics. Exp Cell Res 2004, 295:79-90

16. Sperling C, Schwartz S, Buchner T, Thiel E, Ludwig WD: Expression of the stem cell factor receptor C-KIT (CD117) in acute leukemias. Haematologica 1997, 82:617-621

17. Singh SK, Clarke ID, Terasaki M, Bonn VE, Hawkins C, Squire J, Dirks PB: Identification of a cancer stem cell in human brain tumors. Cancer Res 2003, 63:5821-5828

18. Haegebarth A, Clevers $\mathrm{H}$ : Wnt signaling, Igr5, and stem cells in the intestine and skin. Am J Pathol 2009, 174:715-721

19. Kayahara T, Sawada M, Takaishi S, Fukui H, Seno H, Fukuzawa H, Suzuki K, Hiai H, Kageyama R, Okano H, Chiba T: Candidate markers for stem and early progenitor cells. Musashi-1 and Hes1, are ex- 
pressed in crypt base columnar cells of mouse small intestine. FEBS Lett 2003, 535:131-135

20. Potten CS, Booth C, Tudor GL, Booth D, Brady G, Hurley P, Ashton G, Clarke R, Sakakibara S, Okano H: Identification of a putative intestinal stem cell and early lineage marker, musashi-1. Differentiation 2003, $71: 28-41$

21. Austin J, Kimble J: glp-1 is required in the germ line for regulation of the decision between mitosis and meiosis in C. elegans. Cell 1987, 51:589-599

22. Henrique D, Hirsinger E, Adam J, Le R, I, Pourquie O, Ish-Horowicz D, Lewis J: Maintenance of neuroepithelial progenitor cells by Delta-Notch signaling in the embryonic chick retina. Curr Biol 1997, 7:661-670

23. Varnum-Finney B, Xu L, Brashem-Stein C, Nourigat C, Flowers D, Bakkour S, Pear WS, Bernstein ID: Pluripotent, cytokine-dependent, hematopoietic stem cells are immortalized by constitutive Notch1 signaling. Nat Med 2000, 6:1278-1281

24. Bhardwaj G, Murdoch B, Wu D, Baker DP, Williams KP, Chadwick K, Ling LE, Karanu FN, Bhatia M: Sonic hedgehog induces the proliferation of primitive human hematopoietic cells via BMP regulation. Nat Immunol 2001, 2:172-180

25. Wechsler-Reya RJ, Scott MP: Control of neuronal precursor proliferation in the cerebellum by sonic hedgehog. Neuron 1999, 22:103-114

26. Zhang $Y$, Kalderon D: Hedgehog acts as a somatic stem cell factor in the Drosophila ovary. Nature 2001, 410:599-604

27. Korinek V, Barker N, Moerer P, van DE, Huls G, Peters PJ, Clevers H: Depletion of epithelial stem-cell compartments in the small intestine of mice lacking Tcf-4. Nat Genet 1998, 19:379-383

28. Zhu AJ, Watt FM: Beta-catenin signaling modulates proliferative potential of human epidermal keratinocytes independently of intercellular adhesion. Development 1999, 126:2285-2298

29. Dvorak P, Dvorakova D, Koskova S, Vodinska M, Najvirtova M Krekac D, Hampl A: Expression and potential role of fibroblast growth factor 2 and its receptors in human embryonic stem cells. Stem Cells 2005, 23:1200-1211

30. Yin AH, Miraglia S, Zanjani ED, Almeida-Porada G, Ogawa M, Leary AG, Olweus J, Kearney J, Buck DW: AC133, a novel marker for human hematopoietic stem and progenitor cells. Blood 1997, 90: 5002-5012

31. Nishii T, Yashiro M, Shinto O, Sawada T, Ohira M, Hirakawa K: Cancer stem cell-like SP cells have a high adhesion ability to the peritoneum in gastric carcinoma. Cancer Sci 2009, 100:1397-1402
32. Rezza A, Skah S, Roche C, Nadjar J, Samarut J, Plateroti M: The overexpression of the putative gut stem cell marker Musashi-1 induces tumorigenesis through Wnt and Notch activation. J Cell Sci 2010, 123:3256-3265

33. Haraguchi N, Inoue H, Tanaka F, Mimori K, Utsunomiya T, Sasaki A, Mori M: Cancer stem cells in human gastrointestinal cancers. Hum Cell 2006, 19:24-29

34. Nickoloff BJ, Osborne BA, Miele L: Notch signaling as a therapeutic target in cancer: a new approach to the development of cell fate modifying agents. Oncogene 2003, 22:6598-6608

35. Zheng $X$, Jiang F, Katakowski M, Kalkanis SN, Hong X, Zhang $X$, Zhang ZG, Yang H, Chopp M: Inhibition of ADAM17 reduces hypoxiainduced brain tumor cell invasiveness. Cancer Sci 2007, 98:674-684

36. Sakamoto M, Hirata H, Ohtsuka T, Bessho Y, Kageyama R: The basic helix-loop-helix genes Hesr1/Hey1 and Hesr2/Hey2 regulate maintenance of neural precursor cells in the brain. J Biol Chem 2003, 278:44808-44815

37. Sharff KA, Song WX, Luo X, Tang N, Luo J, Chen J, Bi Y, He BC, Huang J, Li X, Jiang W, Zhu GH, Su Y, He Y, Shen J, Wang Y, Chen L, Zuo GW, Liu B, Pan X, Reid RR, Luu HH, Haydon RC, He TC: Hey1 basic helix-loop-helix protein plays an important role in mediating BMP9-induced osteogenic differentiation of mesenchymal progenitor cells. J Biol Chem 2009, 284:649-659

38. Mitsutake N, Iwao A, Nagai K, Namba H, Ohtsuru A, Saenko V, Yamashita S: Characterization of side population in thyroid cancer cell lines: cancer stem-like cells are enriched partly but not exclusively. Endocrinology 2007, 148:1797-1803

39. Dormeyer W, Van HD, Braam SR, Heck AJ, Mummery CL, Krijgsveld J: Plasma membrane proteomics of human embryonic stem cells and human embryonal carcinoma cells. J Proteome Res 2008, 7:29362951

40. Melchior K, Weiss J, Zaehres H, Kim YM, Lutzko C, Roosta N, Hescheler J, Müschen M: The WNT receptor FZD7 contributes to selfrenewal signaling of human embryonic stem cells. Biol Chem 2008, 389:897-903

41. Katoh $Y$, Katoh $M$ : Hedgehog signaling pathway and gastrointestina stem cell signaling network. Int J Mol Med 2006, 18:1019-1023

42. Katoh $\mathrm{Y}$, Katoh $\mathrm{M}$ : Hedgehog signaling pathway and gastric cancer. Cancer Biol Ther 2005, 4:1050-1054 